POLISH POLITICAL SCIENCE

VOL XXXIX 2010

PL ISSN 0208-7375

\title{
THE UNFULFILLED PROMISE? DELIBERATIVE DEMOCRACY VS. POLITICAL PARTICIPATION
}

\author{
by Maciej Potz
}

The article aims to, first, critically assess the idea and practice of deliberative democracy and, second, find it a proper place in the democratic theory. I start with defining the concept as it emerges from the works of some of its most prominent proponents (such as Fishkin, Cohen or Habermas), reiterating several of the important arguments in support of it. I then present various criticisms of deliberative democracy, regarding philosophical assumptions that inform it (the idea of common good, the conditions of rational deliberation etc.) and its modus operandi (its alleged procedural superiority over aggregative methods). I then offer further criticism of deliberative democracy as a model of democracy, an alternative to the dominant model of representative democracy, arguing from its ineffectiveness in influencing political decisions. Instead, in the final section, I propose to establish deliberation as one of the two criteria of classification and assessment of democratic systems, thus restoring its importance in the democratic theory. 


\section{THE IDEA OF DELIBERATIVE DEMOCRACY}

The term "deliberative democracy" is being employed in a variety of senses, from the broadest appeal of enhancing the role of dialogue and civic participation in public life (thus actually designating a type of political culture) to a much more specific design for a democratic political system. Without dwelling too long on definition problems (which usually are of little scientific interest, anyway), I understand deliberative democracy as a set of discursive procedures through which political preferences of citizens are transformed in the pursuit of common good and political decisions. ${ }^{2}$

This formulation alone shows from the outset why deliberative democracy is usually perceived as an alternative or challenger for representative parliamentary democracy. Whereas the latter merely aggregates the isolated, pre-formed preferences of individuals (usually by means of counting votes in elections), the former allows these preferences to be shaped and changed during discursive encounters with fellow citizens. The character of decisions made in the two models is fundamentally different, too. While electoral vote is about who will be making all the remaining decisions, deliberation concerns specific issues and policy matters. Also, it is claimed, deliberation often leads to consensus and is more conducive to common good than the winner-takes-all aggregative approach.

Deliberative democracy addresses some of the glaring weaknesses of contemporary representative democracies, notably its triple deficit of

1 F.L. Cook, M.D. Carpini, L.R. Jacobs, Who Deliberates? Discursive Participation in America, [in:] Deliberation, Participation and Democracy. Can the People Govern?, S.W. Rosenberg (ed.), New York 2007, p. 30.

2 See: F. Pierzchalski, Deliberacja po polsku - niedościgniony ideał czy rzeczywista praktyka?, paper presented at the international conference „20 lat transformacji w regionie Europy Środkowej i Wschodniej”, Łódź, 23-24 November 2009. The distinction between deliberation and discourse (and other forms of communication, such as discussion etc.) is a valid one (see: J. Sroka, Deliberacja i rzadzenie wielopasmowe. Teoria i praktyka, Wrocław 2009, pp. 31-32, understanding public discourse as a broader, largely informal phenomenon permeating the entire public sphere, deliberation being a more formalized procedure, guided by a set of rules). Since the distinction is not central to my argument, I take some liberties in using these terms. 
participation, representation and responsibility. ${ }^{3}$ The former is resolved by engaging citizens in discussing and deciding on matters of public interest on an on-going basis, instead of just casting vote once every three or four years. The problem of inadequate representation is addressed either in the most radical way by eliminating it altogether when, ideally, the majority of citizens are actively engaged in deliberative processes, or, at least, by making deliberative bodies more representative in terms of their social structure in all relevant respects (whatever they may be in a given situation). With this refined concept of representation, the question of responsibility shifts naturally from the uncontrollable elected officials to deliberating citizens, who are now directly affected by their own political decisions and actions.

The above arguments are largely autotelic, i.e. they regard deliberative democracy as closer to the democratic ideal itself. There is no need, it appears, to further justify why democracy should be more participatory, direct and responsive to the citizens' needs. Some defenses of deliberative democracy are, however, of more instrumental character. For instance, it is suggested that it helps solve some classic problems of the social choice theory, such as the ordering of preferences - either because no voting would be necessary if universal consensus were reached, or because the likelihood of the occurrence of the Arrow's voting cycle is reduced in comparison with aggregative methods. ${ }^{4}$ It is also claimed that deliberative democracy is more successful than liberal constitutionalism in addressing the danger of the tyranny of majority.

Deliberation may also be instrumental in striving for the ideal of an enlightened, rational, truth-seeking citizen. In his classic defense of the freedom of speech John Stuart Mill, going beyond the liberal credo of simply asserting it as an inalienable individual right, demonstrates how unrestricted freedom of expression facilitates better understanding of both the opponent's and one's own position, leads to improved judgment and,

3 M. Potz, Towards non-electoral democracy?, [in:] Gosudarstwo. Politika. Obszcziestwo, I. Batanina (ed.), Tula 2007, pp. 257-260.

4 J. Fishkin, C. Farrar, Deliberative Polling. From Experiment to Community Resource [in:] The Deliberative Democracy Handbook. Strategies for Effective Civic Engagement in the 21st Century, J. Gastil, P. Levine (eds.), San Francisco 2005, p. 76. 
ultimately, to truth ${ }^{5}$ (whatever this may mean in the social context). Now if this right could be connected with political practice of discussing public matters - as it is in deliberative democracy - Mill's argument would draw its teeth and claws. Not only would citizens be equipped with the armor guarding them against encroachments of the state, but they would gain a chance to exchange opinions, formulate their postulates and shape public policies via deliberative forums.

\section{A CRITICAL ASSESSMENT}

\section{COMMON GOOD}

The idea of deliberative democracy is almost universally linked to the concept of common good, which is supposed to be best attainable through deliberation. ${ }^{6}$ This raises several problems, related to both the idea of common good itself and to its allegedly necessary connection with deliberative democracy. If common good is to mean the will of the majority, it is best determined by simply counting the votes. Obviously, however, the term is normally used in the sense of some state of affairs which is desirable and beneficial for all members of political community. Since such state of affairs is empirically impossible (as was powerfully shown by thinkers such as Joseph Schumpeter ${ }^{7}$ or John $\mathrm{Gray}^{8}$ ) - because people have different interests, opinions, value systems etc. - those who opt out of the consensus are usually regarded as not rational enough to see their own good. This way common good becomes a metaphysical concept - a sort of Rousseau's volonté generale - which exists quite independently of the wills of those who are supposed to benefit from it, and which, although

5 J.S. Mill, On liberty, London 1869, ch. II.

6 See: P. Juchacz, Demokracja - Deliberacja - Partycypacja, Poznań 2006, p. 11. R. Riedel, Deliberacja - czyli na czym polega istota demokracji deliberatywnej, „Studia Polityczne" 2009, No. 23, p. 209.

7 J. Schumpeter, Socialism, Capitalism, Democracy, London 1992, ch. XXI.

8 J. Gray, Two Faces of Liberalism, Cambridge 2000. 
utterly devoid of empirical content, may, as we are warned by Isaiah Berlin $^{9}$, turn into an instrument of domination.

How does this relate to deliberative democracy? Its proponents concur in the first part of this reasoning - that people's interests and opinions are varied and irreconcilable - but only with regard to pre-formed opinions and interests, i.e. formed in isolation, prior to confronting them with opinions and interests of others. The process of deliberation, however, has the potential to transform the originally divergent views in the direction of common good.

Now this argument is partly valid - people do often change their mind as a result of discussion. But what if some of them remain unconvinced, as is usually the case? The participants may just finish deliberating and go home, possibly having benefited from the debate in some way. If a decision must be reached, it will normally be determined by voting. In neither case, however, is it justifiable to claim that any kind of common good has been attained, any more than in non-deliberative varieties of democracy.

Another strategy for the advocates of common good is to shape the deliberative forum in such a way as to exclude views that are potentially irreconcilable with the pre-determined outcome of deliberation or at least are based on a different system of norms and values, perhaps incommensurable with the dominant one. Since such incommensurability precludes reaching a consensus, which for some deliberativists seems to be a goal in itself, antagonistic views are dismissed as irrational. This is achieved by setting criteria of access, which usually require that the views presented at the forum are based on universally acceptable justifications rather than mere self-interest and are presented in rational, logical terms, understandable to others. "Deliberative democracy is about reasoning together among equals, and that means not simply advancing considerations that one judges to be reasons, but finding considerations that others can also reasonably be expected to acknowledge as reasons"10, states Joshua

9 I. Berlin, Two Concepts of Liberty, [in:] Four Essays on Liberty, Oxford 1969.

10 J. Cohen, Deliberative Democracy, [in:] Deliberation, Participation and Democracy, op.cit., p. 220. 
Cohen. Similarly, according to James Bohman, deliberation is about putting forward arguments acceptable to others. ${ }^{11}$

As a consequence, people arguing, say, from their religious convictions, especially falling outside of the society's religious mainstream, are excluded. A person's stand on a given political issue can be referred to his or her religious belief, but the belief itself cannot be further justified in terms of public interest. This is because such argumentation, for most religious beliefs, is ultimately reducible to the intrinsically egoistic goal of personal salvation and cannot be genuinely presented in a way that meets the criteria of rationality set out above. Treating such arguments as unfit for deliberation constitutes an exercise of power which seriously distorts the conditions of equality which are among the declared prerequisites of fair deliberation. It may even be impossible in principle to construct a public forum of unconstrained exchange of ideas, free from acts of power and exclusion inherent in all political phenomena. ${ }^{12}$ Proceedings and outcomes of deliberation are strongly dependent on who initiates and convenes a forum, whether the participants know one another, how they assess the chances that the results will be binding etc. ${ }^{13}$

This failure of deliberative democracy as a route to common good is not, nevertheless, in itself a drawback for the whole concept. Rather, the necessary link between deliberation and common good is itself a misconception. If we reformulate the idea of a deliberative forum simply as a place where people exchange ideas, listen and learn from one another, or socialize into the political community ${ }^{14}$, we will be able to retain the value of deliberation without resorting to the unrealistic and potentially dangerous (as engendering domination) notion of common good. Indeed, some proponents of deliberative democracy assume precisely such an unteleo-

11 J. Bohman, Public Deliberation. Pluralism, Complexity, and Democracy, Cambridge, MA 2000, pp. 4-7.

12 See: C. Mouffe, Democracy as Agonistic Pluralism, [in:] Rewriting Democracy, E.D. Ermarth (ed.), Ashgate, Aldershot 2007, pp. 40-43.

13 These points are well demonstrated in M. Button, D.M. Ryfe, What Can We Learn from the Practice of Deliberative Democracy?, [in:] The Deliberative Democracy Handbook..., op.cit., pp. 23-24.

14 R. Riedel, op.cit., p. 210. 
logical approach. Among three basic reasons why deliberation is vital for democracy listed by Peter Levine the first two have nothing to do with common good or indeed any other goal deliberation is supposed to achieve. Instead, it helps citizens rectify their own opinions and "offers democratic leaders better insight into public concerns than elections do." 15 James Fishkin and Cynthia Farrar, setting out the principles of Fishkin's deliberative poll, stress that participants "are not instructed to stick to arguments or to refrain from telling stories, nor are they asked to restrict themselves to appeals to the common good. Appealing to narrower interests is legitimate."16

Jürgen Habermas's approach is more nuanced, too. Deliberative politics, the third way between liberal and republican visions of democracy, at first reading looks like a reformulation of the latter. It shares with it the discursive, communicative mode of opinion - and will-formation, as opposed to the aggregative, market logic of the liberal view. Nonetheless, Habermas criticizes the "ethical overload" of the republican vision, i.e. its insistence of ethical consensus, to the exclusion of other forms of political communication. "The making of norms is primarily a justice issue and is gauged by principles that state what is equally good for all. And unlike ethical questions, questions of justice are not related from the outset to a specific collective and its form of life". An important dimension of politics, indeed the "bulk of political processes" according to Habermas, is bargaining between conflicting interests "without the prospect of consensus", which "cannot be achieved through ethical discourses." More often than consensus, compromise is needed, even if it "may rely of mutual threats."17

To conclude, giving up the pursuit of common good does not strip deliberation of its virtues. It can still help people formulate their standpoints in a more conscious way; it provides them with the opportunity to

15 P. Levine, Getting Practical about Deliberative Democracy, [in:] Philosophical Dimensions of Public Policy, V.V. Gehring, W.A. Galston, New Brunswick (eds.), NJ 2003, p. 77.

16 J. Fishkin, C. Farrar, op.cit., p. 74.

17 J. Habermas, Three Normative Models of Democracy, [in:] Democracy and Difference. Contesting the Boundaries of the Political, S. Benhabib (ed.), Princeton 1996, p. 25. See also: J. Sroka, op.cit., p. 26. 
learn from, and better understand the views and reasons of others, which often leads to enhanced mutual tolerance; and it gives them the motivation to actively engage in (and occasionally influence) public matters, thereby satisfying the natural drive for political participation that, according to Hannah Arendt, is a feature of our human condition. ${ }^{18}$

\section{THE MECHANISM AND OUTCOMES OF DELIBERATION}

It would, however, be a mistake to assume that these potentially beneficial results are automatically generated from any process of deliberation. It is by no means certain that deliberation is always conducive to mutual acceptance and trust between participants of different ethnic, religious, racial and, generally, social backgrounds, or simply holding antagonistic opinions on a subject. After all, discussion involves airing the differences, which may well be augmented rather than reduced in the process - either because insufficient time is available or because, more fundamentally, they are in principle irreducible. Katherine C. Walsh, commending civic dialogue (a sort of preparatory discussion between citizens presenting their standpoints before engaging in deliberation proper) as a welcome introduction - clearing the way - to deliberation (understood as discursive decision-making), is not blind to the potential danger that „dialogue, instead of enabling connections, may exacerbate divides."19 Indeed, according to Joshua Cohen, there is no evidence so far that civic dialogue in fact facilitates deliberation. ${ }^{20}$ Psychologically, it may be better to play down or even conceal some disagreements than to highlight them. ${ }^{21}$

But even if deliberative practices do ultimately lead to a consensus, is this necessarily a desirable outcome? This objection reflects different visions of politics in general and democracy in particular of thinkers such as Habermas, Cohen and other deliberativists on the one hand, and Schmitt, Schumpeter or Mouffe on the other. According to Mouffe's agonistic

18 H. Arendt, On Revolution, London 1990.

19 K.C. Walsh, Democratic Potential of Civic Dialogue, [in:] Deliberation, Participation and Democracy, op.cit., p. 59.

20 J. Cohen, op.cit., p. 224.

21 See I. Shapiro, The State of Democratic Theory, Princeton 2003, p. 27. 
model, politics is the clash of contending views, opinions and interests and every attempt at suppressing them in the name of universal consensus and common good is in fact a concealed act of usurpation. ${ }^{22}$ Arguing from similar premises, Shapiro shows how too smooth a co-operation and agreement between the leading political forces may actually become a political oligopoly disguised as consensualism. ${ }^{23}$ Political consensus is, it appears, a mixed blessing for democracy and pluralism.

Even Jon Elster himself, sympathetic to the "forum" (as opposed to "market") view of politics and one of the forefathers of deliberative democracy, declares that he "would in fact have more confidence in the outcome of a democratic decision if there was a minority that voted against it, than if it was unanimous," 24 Elster's balanced account merits attention, for it, while supportive to deliberation, pinpoints its possible shortcoming, as well. In particular, he shows the idea's vulnerability on psychological grounds. It is unrealistic to suppose that the participants of the deliberative forum will behave rationally and unselfishly, even if it were in principle possible and normatively desirable to do so. Instead, many of them will act in a conformist way, ready to accept the majority view, either because they are not strong enough to stand the pressure and reject it, ${ }^{25}$ or because they perceive their truly preferred option as infeasible and gradually come to espouse the majority's choice as their own. ${ }^{26}$ Consequently, the preferences are transformed not as a result of rational discourse but through psychological mass effects.

Furthermore, the problem with the postulated unselfishness of deliberation - i.e. the requirement that the propositions and arguments are put forward with public interest in view - is that every option benefits some

22 C. Mouffe, op.cit., pp. 42-43. See also: On the Political, New York 2005.

23 I. Shapiro, op.cit., pp. 60-61.

24 J. Elster, The market and the forum: three varieties of political theory, [in:] Foundations of Social Choice Theory, J. Elster, A. Hylland (eds.) Cambridge University Press, Cambridge 1986, p. 117.

25 This is, to be sure, a commonplace of social psychology. See: E. Aronson, The Social Animal, New York 2008, ch. II.

${ }^{26}$ Ibidem, pp. 117-118. 
group at the expense of others ${ }^{27}$ (if it benefits no one it makes little sense, anyway). Thus, any choice made via deliberation means giving up one's selfish interests in the name of common good by some, but fulfilling one's selfish interests in the name of common good for others, even though everyone was arguing in a rational (in deliberativist sense) way.

\section{DELIBERATIVE DEMOCRACY QUA MODEL OF DEMOCRACY}

Let us now turn to the assessment of deliberative democracy as a model of democracy. It has often been presented as a participatory alternative to the shortcomings of representative democracy. But if deliberative democracy is to mean a set of measures providing rank-and-file members of the political community with an opportunity to merely voice their opinions, demands, complaints - such as various consultative procedures, opinion polls, various citizen forums, workshops etc. - it is not participatory democracy at all; rather, it is a welcome but secondary addition to the rule of representatives.

If, on the other hand, deliberative democracy is understood as participatory democracy proper - a procedural setting whereby the fundamental political decisions are made by citizens themselves - the concept is misconceived. It tends to overemphasize the very act of deliberation, while the substantial difference lies in the decision-making power of citizens, which in participatory democracy extends to all important questions and in representative variety is confined to the sole decision of who governs.

Thus the central problem of deliberative democracy, on this analysis, is its effectiveness. Can political decisions be made or at least influenced by deliberative procedures? The question is deemed significant by various deliberative theorists themselves. "One of the necessary conditions for legitimacy is that deliberation has some impact" - asserts Dryzek, listing major tasks of deliberation. "The most obvious way to seek impact would be for the results of deliberation to somehow be embodied in public policy"..28

\footnotetext{
27 Ibidem, pp. 118-119.

28 J. Dryzek, Theory, Evidence and Tasks of Deliberation, [in:] Deliberation, Participation and Democracy, op.cit., p. 242.
} 
Similarly, for Lyn Carson and Janette Hartz-Karp the first of the "three criteria for a fully democratic deliberative process" is "Influence: The process should have the ability to influence policy and decision making." 29

This, however, is very hard to achieve, as deliberative practitioners are ready to admit. Ned Crosby, the inventor and professional organizer of citizen juries, an interesting and by now quite popular (also outside of the United States) form of a deliberative forum, had to close his Jefferson Center (the institution organizing citizen juries and other deliberative events) in 2002, for "it was clear that the work of the center was not having a large enough impact on public policy to warrant its continuation" 30 . There were, to be sure, instances of more influential deliberative initiatives, such as various events conducted in Australia ${ }^{31}$. Their common feature was, however, that they were designed and financed by the city or state authorities and it was these authorities' free and unforced decision to take the results into consideration. In other words, the deliberative procedures are not an institutionalized and permanent feature of political systems, but rather haphazard events whose political impact is entirely dependant on the good will of the rulers. ${ }^{32}$

29 L. Carson, J. Hartz-Karp, Adapting and Combining Deliberative Designs, [in:] The Deliberative Democracy Handbook..., op.cit., p. 122.

30 N. Crosby, D. Nethercut, Citizens Juries, [in:] The Deliberative Democracy Handbook..., op.cit., p. 116.

31 L. Carson, J. Hartz-Karp, op.cit., pp. 128-134. For a Polish example see: M. Kopiński, Co poznaniacy zrobia ze stadionem, „Gazeta Wyborcza” 23.11.2009 (a deliberative poll, organized in Poznań under the supervision of James Fishkin, concerning the future of the municipal football stadium). The detailed findings of the poll are available on the website of The Center for Deliberative Democracy of Stanford University: http://cdd. stanford.edu/polls/poland (10.03.2010).

32 The actual political ineffectiveness of deliberative methods is perhaps best illustrated by their advocates' proud boasting whenever a politician pays lip-service to deliberative democracy, as did reelection-seeking Gordon Brown when he "endorsed citizen juries" (he even appeared at one of them) and "seemed very serious about closing the persistent "democratic deficit»". J. Snider, New British PM Wants National Citizen Juries to Discuss Constitutional Reforms This Coming Year, "Journal of Public Deliberation", www.auburn.edu/academic/liberal_arts/poli_sci/journal_public_deliberation/articles/ New\%20British\%20PM\%20Wants.htm (10.03.2010). 
In similar vein, Michael Saward, categorizing deliberative forums according to their representative/non-representative and formal/informal character, reflects rather pessimistically that "most deliberative forums do not involve citizens directly; and the ones that $d o$, generally lack decisional power and broader democratic legitimacy." 33 Political forums where decisions are made, both representative and non-representative (respectively, e.g., parliaments and courts), are non-participatory. Participatory forums, on the other hand (citizens juries, opinion polls etc.) perform a consultative role at best.

If, as Cohen argues, “...democracy, no matter how fair and no matter how participatory, is not deliberative unless actual reasoning is central to the process of collective decision-making" ${ }^{34}$, then hardly any deliberative democracy exists in the various procedures of public discourse anywhere in the world today.

\section{DELIBERATION AS A FEATURE OF DEMOCRATIC SYSTEMS}

In an attempt to put deliberation into a different context, let us suggest the following typology of models of democracy, featuring some examples of past, present and even hypothetical models.

The two dichotomized criteria of the above typology address two fundamental questions of democratic theory: "Who governs?" and "In what way are the decisions made?" The former is answered by the classic distinction between direct and representative kinds of democracy, where the power is in the hands of, respectively, all citizens (whatever limitations may apply to this category), and a minority group, usually elected, but possibly selected by some other democratic procedure. The latter criterion - how the decisions are reached - is where deliberation enters the scene. Understood procedurally, as a way of decision-making, this distinction may apply to both direct and representative varieties of democracy. This

33 M. Saward, Democracy and Citizenship: Expanding Domains, [in:] The Oxford Handbook of Political Theory, J. Dryzek, B. Honig, A. Philips (eds.), Oxford 2006, p. 405.

34 J. Cohen, op.cit., p. 220. 
Tab. 1: Typology of models of democracy

\begin{tabular}{|c|c|c|c|}
\hline & \multicolumn{2}{|l|}{ Who makes policy decisions? } \\
\hline & & Demos & Representatives \\
\hline \multirow{2}{*}{ 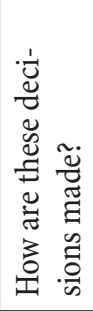 } & In isolation & $\begin{array}{l}\text { A } \\
\text { Referendum democracy }\end{array}$ & $\mathrm{D}$ \\
\hline & $\begin{array}{l}\text { Via } \\
\text { deliberation }\end{array}$ & $\begin{array}{l}\text { B } \\
\text { - Athenian democracy } \\
\text { - Committee democracy } \\
\text { (e.g. Polish noblemen democracy) }\end{array}$ & $\begin{array}{l}\text { C } \\
\text { - Parliamentary democracy } \\
\text { - Demarchy }\end{array}$ \\
\hline
\end{tabular}

is precisely why deliberative democracy does not designate a model of democracy, with a complete institutional setting, but rather an important feature of democratic systems ${ }^{35}$.

The deliberative mode of deciding political issues is here juxtaposed with making decisions in isolation, without discussing the matter under consideration with fellow decision-makers. The distinction has been deemed important by many political thinkers ${ }^{36}$, and for good reasons. The opportunity to expose one's views to review and possible criticism from others constitutes a safeguard, to some degree at least, from the danger of uninformed, one-sided judgements. This is not to say that an isolated decision-maker must by definition be ignorant and selfish ${ }^{37}$, but it certainly

35 This typology resembles Ackerman's and Fishkin's classification (B. Ackerman, J. Fishkin, Deliberation Day, “The Journal of Political Philosophy" 2002, vol. 10, No. 2, p. 150). The important difference is that while I am concerned with models of democracy, they consider various democratic procedures that fit into the four fields. The minor differences are that they talk about types of public opinion (rather than modes of decision-making) and use different examples

36 See: G. Sartori, The Theory of Democracy Revisited, Chatham, NJ 1987, distinguishing sharply between referendum democracy and proper participatory democracy (pp. 111-114); H. Arendt, op.cit.

37 Perhaps one can think of individual, non-collective deliberation, in the sense of judging based on public criteria of justice, but without actual discursive encounters with others. This is how John Dryzek interprets Rawls's Theory of Justice. See: J. Dryzek, op.cit., pp. 236-238. 
requires from him much more effort to avoid these pitfalls, and it still may not be possible to fully understand the positions and, especially, emotions of others without face-to face contact.

An important body of evidence in support of the choice of the mode of decision-making as a criterion of the typology of democracies is provided by the study of the actual deliberative procedures. James Fishkin, whose deliberative polls are not only public events but scientific experiments, too, demonstrated - by surveying participant before and after the event - a significant shift in opinions on the subject of the debate. According to his and Farrar's account, the support for a given policy in a deliberative poll organized in New Haven in 2002 dropped from the initial 80\% to $42 \%$ as a result of deliberation. ${ }^{38}$ Findings from deliberative polls from around the globe provide evidence to the same effect. ${ }^{39}$

Now it could be argued that the above justifications are somewhat contradicted by my earlier critique of the mechanisms of a deliberative forum, with its psychological pressures towards conformity and the threat of domination inherent in the very act of structuring of the forum. But the present argument is not normative at all. It merely says that the way decisions are made - by means of counting isolated preferences or by transforming them during public encounters with fellow citizens - does make a difference, no matter how we may judge the two types of procedures themselves and their outcomes. What constitutes a fulfilment of the democratic ideal for a deliberativist, for an aggregativist may well amount to a regrettable abuse of this ideal by demagogues exploiting the weaknesses of human nature. Neither of them can deny, however, the significance of the distinction between deliberative and non-deliberative decision-making for democratic theory and practice.

The content of Table 1 requires some justification. It is meant as an illustration rather than exhaustive list of models of democracy pertaining to each type. Field A represents what may be labelled "referendum democracy." It is direct, i.e. all citizens can participate in the actual decision-

38 J. Fishkin, C. Farrar, op.cit., p. 69.

39 See: Stanford University's Center for Deliberative Democracy website: http://cdd. stanford.edu/polls for detailed results, questionnaires and methodology of deliberative polls. 
making by voting on laws, policy proposals etc,. either in a traditional referendum, or its electronic version. And it is non-deliberative, because individual decisions are made in relative isolation, outside of any institutionalized public forums ${ }^{40}$.

Square B - direct democracy based on deliberation - contains, rather unsurprisingly, Athenian democracy, for some still an embodiment of the democratic ideal itself. The Athenian system of collective rule involved equal citizens discussing and deciding public matters on the agora ${ }^{41}$, the mother of all deliberative forums. The realisation of the idea of direct participation coupled with deliberation in the contemporary world, with its obvious limitations of size (infeasibility of actual gathering of all citizens in one place) would amount to a model I termed "committee democracy." Generally speaking, it is based on a system of citizen bodies of manageable size ("committees"), where all citizens willing to participate discuss public matters and make binding decisions on them. The votes of the individual committees are then simply counted to reach the final decision.

An interesting, though perhaps not obvious, example of such a model is the political system of Poland in the period of, roughly, $16^{\text {th }}$ to $18^{\text {th }}$ century, often referred to as noblemen's democracy. It was founded on territorial gatherings (sejmiki) of all qualifying citizens, where public matters were debated and policy decisions made. The reason why this system is usually treated as representative democracy is that its central institution - Sejm - was the gathering of representatives from all administrative units of the country. These representatives were not, however, equipped with a free mandate. On the contrary, they were obligated to act within the instructions issued by the sejmik that sent them ${ }^{42}$ (this, by the way, is the reason why they got, at times, so persistent and uncompromising). In other words, they were more delegates than representatives and the Sejm was, to a large extent, a technical way of aggregating the decisions of the basic-

40 Critic of this kind of democracy, relating to the problems of popular ignorance, agenda-setting as a source of power etc. are, to be sure, well known in the democratic theory. To consider them here is, nonetheless, beyond the scope of this article.

41 Later, Pnyx hill was actually used (see M. Hansen, The Athenian Democracy in the Age of Demosthenes, trans. J.A. Crook, Norman, OK 1999, p. 128).

42 See: T. Maciejewski, Historia ustroju Polski, Koszalin 1998, pp. 54, 57. 
level bodies. If some negotiation and compromise was possible among the Sejm participants, it was again within the scope of the instructions they were bound with.

The description of the various models of democracy I am offering is, no doubt, oversimplified and inaccurate, perhaps to a degree unacceptable for a historian. For instance, to see Athenian democracy in that way requires one to omit from consideration the denial of political rights to the majority of people living in the polis or gross abuses of freedom, at least from the viewpoint of the liberal tradition. ${ }^{43}$ But such ideal-typification is a perfectly justifiable analytical tool for a political scientist, whose purpose is to highlight some significant aspects of reality at the expense of others. Indeed, each description is, necessarily, selective, just as, more generally, each cognitive act is theory-based. Here the emphasis on the political characteristic of the ancient agora and the imperative mandate of the delegates in the old Polish state serves to demonstrate the logic of these two models of direct deliberative democracy.

Both models of representative democracy included here fall within its deliberative variation. One is parliamentary democracy, the most widespread form of contemporary democratic systems, where elected representatives deliberate among themselves to reach political decisions. The other, demarchy, was proposed by Australian philosopher John Burnheim. ${ }^{44}$ It consists of a system of committees with authority over various policy areas on a given territory (functional, rather than territorial division). A crucial feature of the system, making it more participatory and egalitarian (resembling, in this respect, Athenian democracy), is that the committee members are selected by lot from among a group of volunteers, rather than elected. This solves, to a large extent, the problem of partocracy, for no party affiliation (or, indeed, any other characteristic such as wealth, social status or influence) modifies chances of occupying power positions. Demarchy is still, however, a representative form of democracy, since only

43 B. Constant, The Liberty of the Ancients Compared with that of the Moderns, [in:] B. Constant, Political Writings, B. Fontana (ed.), Cambridge 1988, pp. 309-328; G. Sartori, op.cit., ch. X.

44 J. Burnheim, Is Democracy Possible? Polity Press, Cambridge 1985. 
a small minority of citizens actually get to serve on the committees. ${ }^{45}$ In other words, while the difference in the mode of selection of representatives between parliamentary democracy and demarchy (election vs. drawing lots) is significant and consequential, it is still a difference within field C of the typology.

The relative scarcity of the forms of democracy included in the table reflect the premise that I am concerned with models of democracy, i.e. full institutional settings by means of which political community governs itself, rather than isolated procedures ${ }^{46}$ (plus, the list is not comprehensive ${ }^{47}$ ). Nonetheless, it would be possible to use this same framework to classify democratic procedures, too. For instance, the now unoccupied square D (representative non-deliberative) could host American electoral college, while referenda and popular initiatives would be examples of direct nondeliberative procedures (A) functioning within the model of parliamentary democracy. Field B, representing direct deliberative democracy - the ideal cherished by many radical critics of contemporary democracy - would be especially rich in solution enhancing citizens' participation in public life, ranging from town or community meetings, still held at district or canton

45 This is not recognized by some commentators. See: M. Marczewska-Rytko, Demokracja bezpośrednia w teorii i praktyce politycznej, Lublin 2001, pp. 42-43.

46 This is also why electronic democracy (e-democracy) is not included. Understood as the use of information technology in various democratic procedures, it can facilitate the operations of both parliamentary democracy (e-voting in elections) and referendum democracy (e-voting in referenda), as well as support deliberative procedures (internet forums). Indeed, it may even make some of them practically possible in the first place (referendum democracy). Still, it does not make electronic domocracy a distinctive model of democracy itself. (On e-democracy see: T. Westen, E-Democracy: Ready or Not, Here It Comes, "National Civic Review" 2000, vol. 89, No. 3; M. Marczewska-Rytko, op.cit., ch. VIII).

47 An interesting model which actually crosses through sections A and C was proposed by Marcus Schmidt, who suggested adding an "electronic chamber" to the Danish parliament. The additional chamber would consist of 70.000 randomly chosen citizens who would vote, in real time, on any act adopted by the parliament. If the citizen chamber disagreed, the issue would be decided by referendum. (B. Świderski, Gdańsk i Ateny, Warszawa 1996, pp. 227-228). This model combines the features of deliberative representative (parliamentary) and non-deliberative direct democracy. 
levels in Switzerland, to revolutionary committees flowering spontaneously in the past, to various contemporary deliberativists' devices (citizens juries, planning cells, deliberative polls, Deliberation Day etc.).

\section{CONCLUSION}

The problem with deliberation democracy is, in a nutshell, this: the more it is participatory, the less powerful it becomes. Since it is not possible to establish it as a model of democratic political system in its own right, I insisted on treating deliberation as one of the defining characteristics of democratic models.

On the normative side, linking deliberative democracy with the common good actually does a disservice to the efforts to overcome the domination of the few in representative democracy. The obvious failure of this unattainable goal plays into the hands of critics who dismiss the whole idea of participation as utopian. Deliberation certainly constitutes an added value to such crude forms of direct governance as referendum democracy, but, dissociated from the participatory decision-making procedures, it may become just a fig-leaf for representative partocracy.

The way to reclaim citizens for democracy, to restore their trust in its institutions, to motivate them to engage in public life - is, in the first place, to give them more power, not more opportunities to debate. Once they are empowered to make policy decisions (as opposed to electoral decisions only), the chances are that they will find it more fruitful and rewarding to exchange views and opinions and weigh arguments - to deliberate - with their fellow citizens. 